\title{
Vermikompostun Ayçiçeği (Helianthus annuus L.) Çeşitlerinin Fenolojik ve Morfolojik Özelliklerine Etkisi
}

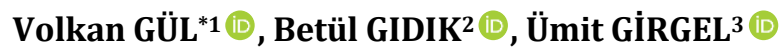 \\ 1,2Bayburt Üniversitesi, Uygulamalı Bilimler Fakültesi, Organik Tarım İşletmeciliği Bölümü, 69000, Bayburt, \\ Türkiye \\ ${ }^{3}$ Bayburt Üniversitesi, Aydıntepe Meslek Yüksekokulu, Gıda İșleme Bölümü, 69000, Bayburt, Türkiye
}

(Alınış / Received: 29.03.2019, Kabul / Accepted: 19.09.2019, Online Yayınlanma / Published Online: 30.12.2019)

\author{
Anahtar Kelimeler \\ Vermikompost, \\ Ayçiçeği, \\ Çiçeklenme süresi, \\ Fenolojik ve morfolojik \\ özellikler
}

\begin{abstract}
Özet: $\mathrm{Bu}$ çalışma Bayburt Üniversitesine ait deneme arazisinde farklı dozlarda vermikompost $(0,100,200,300$ ve $400 \mathrm{~kg} / \mathrm{da})$ uygulamalarında yağlık ayçiçeği çeşitlerinin (Pioneer 64LC108 ve Pioneer 64LE119) fenolojik ve morfolojik özelliklerini belirlemek amacı ile 2018 yılında yapılmıştır. Araştırma Tesadüf Blokları Deneme Deseni' ne göre üç tekerrürlü olarak yapılmış olup, çalıșmada çıkış, tabla olum, çiçeklenme ve olgunlaşma süresi (gün), yaprak sayısı (adet), yaş ve kuru sap verimi (kg/da), yaş dolu, yaş boş ve kuru tabla verimi (kg/da) incelenmiştir. Denemede çıkış, tabla olum, çiçeklenme ve olgunlaşma süresi, yaprak sayısı ve yaş tabla verimi Pioneer64LE119 çeşidinde fazla olurken, yaprak sayısı, yaş ve kuru sap verimi, yaş dolu, yaş boş ve kuru tabla verimi ise Pioneer64LE119 çeşidinden elde edilmiştir. Vermikompost dozlarınızda dekara $200 \mathrm{~kg}$ uygulandığında en fazla çıkış, tabla olum, olgunlaşma süresi ve kuru sap verimi elde edilirken, dekara $300 \mathrm{~kg}$ vermikompost dozunda ise en fazla yaprak sayısı, yaş sap verimi ve çiçeklenme süresi elde edilmiştir. Sonuç olarak; sap verimi değerleri dikkate alındığında 300 kg'lık vermikompost dozu ve Pioneer 64LC108 çeşidi önerilebileceği kanaatine varılmıştır.
\end{abstract}

\section{The Effect of Worm Fertilizer on Phenological and Morphological Properties of Sunflower (Helianthus annuus L.) Cultivars}

\author{
Keywords \\ Vermicompost, \\ Sunflower, \\ Flowering period, \\ Phenological and \\ morphological features
}

\begin{abstract}
This study was carried out in 2018 in order to determine the phenological and morphological properties of oil sunflower varieties (Pioneer 64LC108 and Pioneer 64LE119) in different doses of vermicompost $(0,100,200$, 300 and $400 \mathrm{~kg} \mathrm{da}^{-1}$ ) in the trial area of Bayburt University. The study was carried out with three replications according to the Randomized Blocks Trial Design. In the study, the output, table burn, flowering and ripening time (days), number of leaves (pieces), age and dry stalk yield ( $\mathrm{kg} \mathrm{da}^{-1}$ ), age full, wet age and dry tray yield (kg da1 ) were investigated. In the experiment, the output of the plate, flowering and ripening time, number of leaves and age table yield was higher in Pioneer64LE119 variety, while the number of leaves, age and dry stalk yield, age filled, wet and dry table yield were obtained from Pioneer64LE119 variety. When dosing $200 \mathrm{mg}$ per hectare in your vermicompost doses, the most output, tabula, ripening time and dry stalk yield were obtained, while the maximum number of leaves, age stalk yield and flowering time were obtained at $300 \mathrm{~kg}$ vermicompost dose per decare. As a result; Considering the shelf yield data, $300 \mathrm{~kg}$ of vermicompost dose and Pioneer 64LC108 variant were suggested.
\end{abstract}

\section{Giriş}

İnsanoğlu geçmişten günümüze hayatını devam ettirebilmek için beslenme ihtiyacını avcıllk ve toplayıcılık ile tedarik ederken yerleşik hayata geçmesi ile birlikte doğadaki yabani formdaki bitkileri kültüre alarak tarımsal faaliyetlere başlamıştır. Yerleşik hayattan sonra hızla artan dünya nüfusa bağlı olarak beslenme ihtiyacı artmış, özellikle sanayileşmeyle birlikte tarım alanları hızlı bir şekilde 
daralmaya başlamıştır. Beslenme ihtiyacını karşılayabilmek için birim alandan en fazla ürün elde edilme yollarına gidilmiștir. Dünyada olduğu gibi ülkemizde de gida sektörünün önemli hammaddeleri olan bazı bitkilerin hem ekim alanlarının hem de birim alandan elde üretim miktarının artırılması zorunlu hale gelmiştir. İnsan beslenmesinde yüksek enerji kaynağına sahip bitkisel kökenli yağlar içerisinde ayçiçeği, tohumlarında yüksek oranda içerdiği yağ miktarı (\%25-50) ve ülkemizde bitkisel yağ üretiminin \%74'ü karşıladığından yağ sanayisinin en önemli hammaddelerinden bir tanesidir [1,2]. Ayçiçeği adaptasyon kabiliyeti sayesinde çoğu bölgemizde yetişme olanağına sahip olduğundan bitkisel yağ tüketim ihtiyacını karşılayabilmek için Trakya haricinde farklı bölgelerde ayçiçeği yetiștiriciliğinin artırılması uygun olacaktır.

Ayçiçeği yüksek oranda doymamış yağ asitleri olan oleik, linoleik ve linolenik yağ asitleri sayesinde kalp ve damar rahatsızlıkları ve kolesterol tehlikesinin azaltması ve A, D, E, K vitaminlerini içerdiğinden sağlık açısından oldukça önemlidir [3]. Ayçiçeği yağı yemeklerde ve kızartmalarda kullanılmasının yansıra, yağı çıkarıldıktan sonra elde edilen küspesi ve bitki artıkları yeșil yem veya silaj yapılarak (\%32.3 protein) hayvan yemi olarak kullanılmaktadır. Sanayi sektörünün boya, kâğıt, plastik, sabun, kozmetik, yalıtım malzemesi gibi ürünlerin hammaddesi olarak kullanılmaktadır [4].

Birim alandan en fazla verim almak için kontrolsüz bir şekilde kullanılan kimyasal gübreler ve tarımsal ilaçlar çevre kirliliğine yeraltı su kaynaklarının kirlenmesine ve yetiştirilen ürünlerinde meydana gelen kimyasal kalıntıların insan ve hayvan sağlığını ciddi anlamda tehdit etmeye başlamasına neden olduğu tespit edilmiştir [5]. Bu yüzden doğal dengeyi bozmayan insan ve çevreye dost tamamen doğal yollarla elde edilen organik gübreler ile toprağın korunması sayesinde sadece verim artışında değil aynı zamanda sağlıklı ürün yetiştiriciliğinde de artış sağlanması hedeflenmiştir [6]. Her bitkide olduğu gibi ayçiçeğinde de doğru gübreyi kullanma ürün miktarını ve kalitesini olumlu yönde artırmaktadır. Toprağın doğal dengesini bozmadan kimyasal gübrelerden uzak iyileşmesini sağlayacak materyallerden birisi de solucan gübresidir. Solucan gübresi, ahır gübresi ve ağaç kabukları, yaprak, saman, sebze ve meyve artıkları gibi materyaller ile oluşturulan kompostla beslenen solucanların çıkardıkları dışkılardan elde edilen ve vermikompost olarak adlandırılan gübredir. Genel olarak siyah toprak renginde, kötü kokusu olmayan bitki besin elementlerince zengin, insan sağlığını tehdit etmeyen tamamen doğal gübrelerdir [7]. Vermikompost gübreler organik tarım için sürdürülebilirliği sağlayarak ve tüketim sonucu ortaya çlkan katı atıkların işlenerek ekonomiye büyük fayda sağlayan yöntemlerden bir tanesidir [8]. Domates bitkisi ile ilgili yapılan çalışmada; dekara 15 ton vermikompost uygulandığında verimi artırdığı, toprağın N, P, K, Ca,
Zn, Mn gibi element miktarında artış göstererek fiziksel yapısını olumlu yönde değiştirdiği gözlemlemişlerdir [9]. Domates ve marul bitkisi ile yapılan çimlendirme testinde, bitki gelişimi üzerine vermikompost gübresinin büyükbaş hayvan gübresinden daha iyi sonuçlar verdiğini gözlemlemişlerdir [10]. Patates bitkisinde en iyi verim parametreleri dekara 12 ton solucan gübresi uygulandığında elde edilmiştir [11]. Marul bitkisine uygulanan vermikompost gübrenin bitkinin yapraklarında fazla miktarda $\mathrm{Mg}, \mathrm{Fe}, \mathrm{Zn}, \mathrm{Cu}$ elementleri olduğu bitki besleme yönünden olumlu sonuçlar doğurduğunu tespit etmişlerdir [12]. Farklı dozlarda vermikompost uygulanan ayçiçeğinde doza bağlı olarak bitkinin veriminde, yağ oranında, tabla çapında ve bitki boyunda önemli ölçüde artış olduğu gözlemlenmiştir [13]. Kırmızı baş lahana üretiminde vermikompost uygulamasının bitki kalite parametreleri üzerine pozitif etkisi olduğunu tespit etmişlerdir [14]. Vermikompost gübresinin kimyasal gübreye kıyasla çileğin kalitesini artırdığını belirtmişlerdir [15].

Bu çalışmada, Bayburt ekolojik koşullarında ayçiçeği çeşitlerine uygulanan farklı dozlarda solucan gübresinin fenolojik ve morfolojik özellikler üzerinde etkileri incelenmiştir.

\section{Materyal ve Metot}

Deneme Bayburt Üniversitesi'ne ait deneme arazisinde 2018 yllında yürütülmüştür. Araştırma arazisi denizden 1700 m yükseklikte yer almaktadır. Bayburt iline ait uzun yllar ve 2018 yılı yetiştirme ayları yağış, sıcaklık ve bağıl nem ortalama değerleri Bayburt ili meteoroloji istasyonundan alınmış ve Tablo 1'de sunulmuştur.

Bayburt Üniversitesine ait bilimsel araştırma yapılan arazi toprağının bünyesi "killi" olarak tespit edilmiştir. pH değeri 7.75 olarak belirlenmiştir. Elde edilen sonuca göre hafif alkali olduğu görülmüştür. Deneme alanı toprağının kireç oranı \% 9.3 (kireçli), toplam tuz oranı \% 0.047 (tuzsuz), organik madde oranı \% 0.99 (çok az), fosfor miktarı $11.44 \mathrm{~kg} / \mathrm{da}$ (fazla) ve potasyum miktarı $80.3 \mathrm{~kg} / \mathrm{da}$ (fazla) olarak belirlenmiştir. Araştırma merkezinde bulunan deneme alanına ait toprak örneği sonuçları [16]'nın vermiş olduğu değerlendirme kriterlerine göre; toprağın kireçli, tuzsuz, organik madde yönünden zaylf, fosfor ve potasyum yönünden ise yeterli olduğu tespit edilmiştir. Gümüşhane/Şiran ilçesinde özel bir işletmeden alınan ve deneme alanında kullanılan Vermikompost gübrenin kimyasal özellikleri Tablo 2'de verilmiştir.

Çalışmada Pioneer 64LC108 ve Pioneer 64LE119 yağlık ayçiçeği çeşitleri materyal olarak kullanılmıştır. Deneme alanına vermikompost (solucan gübresi) gübrelerinin $(0,100,200,300$ ve $400 \mathrm{~kg} / \mathrm{da}$ ) belirli miktarları ekimden 15 gün önce ilave edilmiştir. 
Tablo 1. Bayburt iline ait 1980-2018 yılları arası iklim ortalaması ve 2018 yılı bazı iklim verileri

\begin{tabular}{lccc}
\hline \multicolumn{1}{c}{ Aylar } & Aylık Ort. Yağıs (mm) & Aylık Ort. Sıcaklık ( $\left.{ }^{\circ} \mathbf{C}\right)$ & Aylık Ort. Nispi Nem (\%) \\
\hline Nisan & $\mathbf{1 9 8 0 - 2 0 1 8}$ yıllarına ait aylık ortalama yağıș, sıcak ve nispi nem ortalamaları \\
Mayıs & 64.6 & 7.2 & 58.1 \\
Haziran & 77.4 & 11.6 & 58.1 \\
Temmuz & 47.1 & 15.4 & 55.1 \\
Ağustos & 21.6 & 19.0 & 50.6 \\
Eylül & 14.2 & 15.0 & 49.9 \\
\hline Ort. & 45.0 & 14.5 & 50.5 \\
\hline \multicolumn{5}{c}{} & 13.8 & 53.7 \\
\hline Nisan & 44.9 & 9.5 & 42.5 \\
Mayıs & $\mathbf{2 0 1 8 ~ y ı l ı n a ~ a i t ~ a y l ı k ~ o r t a l a m a ~ y a g ̆ ı s ̦ . ~ S ı c a k ~ v e ~ n i s p i ~ n e m ~ o r t a l a m a l a r ı ~}$ & 64.8 \\
Haziran & 9.6 & 13.3 & 62.0 \\
Temmuz & 122.3 & 16.6 & 49.4 \\
Ağustos & 81.3 & 20.8 & 44.5 \\
Eylül & 28.9 & 20.3 & 51.2 \\
\hline Ort. & 5.9 & 20.0 & 52.4 \\
\hline
\end{tabular}

Tablo 2. Vermikompost gübrenin kimyasal özellikleri

\begin{tabular}{|c|c|}
\hline Analiz Adı & Vermikompost \\
\hline $\mathrm{PH}$ & 9.46 \\
\hline Nem (\%) $^{\circ}$ & 25.7 \\
\hline $\begin{array}{c}\text { İletkenlik (dS m}{ }^{-1} \text { ) } \\
\text { Toplam (Hümik +fülvik asit) } \\
(\%)\end{array}$ & 3.50 \\
\hline Organik Madde (\%) & 50.20 \\
\hline Organik Azot (\%) & 0.82 \\
\hline $\mathrm{P}_{2} \mathrm{O}_{5}(\%)$ & 1.78 \\
\hline $\mathrm{K}_{2} \mathrm{O}(\%)$ & 0.62 \\
\hline $\mathrm{Ca} \mathrm{( \% )}$ & 0.81 \\
\hline $\mathrm{Mn} \mathrm{( \% )}$ & 0.06 \\
\hline
\end{tabular}

Çalışma, her parselde ekim şekli sıra arası $70 \mathrm{~cm}$, sıra üzeri $25 \mathrm{~cm}$ olacak şekilde Tesadüf Blokları Deneme Deseni' ne göre üç tekerrürlü olarak hazırlanmıștır. Ekim işlemi baharın ilk ayının ikinci haftasında (15 Nisan) belirlenen sıra arası ve sıra üzerine her ocağa üç tohum gelecek şekilde elle yapılmış, akabinde çıkıştan iki üç hafta sonra belirlenen sıralar üzerinde bir ayçiçeği fidesi kalacak şekilde tekleme yapılmıştır. Ekimden hasat dönemine kadar yabancı otlar ile mücadele etmek için iki kere çapalama yapılmıș, tabla olum, çiçeklenme ve tane olum dönemlerinde yağmurlama sulama yöntemi ile sulama yapılmıștır. Hasat işlemi tane dolum süresinden sonra bitkide meydana gelen birtakım değişimlere bağlı olarak (steril ve fertil çiçeklerin döküldüğü, brakte yaprakları sarıdan kahverengiye döndüğü ve tablanın baş kısmının kahve rengi olduğu evre) tohumların olgunlaşma evresini tamamladıktan sonra parsellerin kenarlarında bulunan siralar kenar tesiri olarak değerlendirilerek, orta kısımda kalan sıralardan yirmi bitki el ile Eylül'ün dokuzunda hasat edilmiștir. Elde edilen materyaller ile çıkış süresi, çiçek açma süresi, olgunlaşma süresi, yaprak sayısı, yaş ve kuru sap verimini belirlemeye çalışılmıştır $[17,18,19]$.

Araştırma sonuçları, SPSS bilgisayar programı ile istatistiki analizleri yapılmış, elde edilen ortalamalar arasındaki farklar ise önemlilik düzeylerine göre Duncan Çoklu karşılaştırma testi ile kontrol edilmiştir [20].

\section{Bulgular}

Fenolojik gözlemlerde çeşitler bazında çıkış, tablo olum, çiçeklenme ve olgunlaşma süresi bakımından önemli bir farklılık görülmemiştir. Farklı solucan gübresi uygulanan yağlık ayçiçeği çeşitlerinden elde edilen çıkış, tablo olum ve olgunlaşma süresi bakımından fark görülmemiş iken, tablo olum süresine ait, çeşit $\mathrm{x}$ solucan gübresi etkileșimi ile olgunlaşma süresi çeşit x solucan gübresi etkileşimi $\mathrm{p}<0.05$ göre çiçeklenme süresi ve çeşit $\mathrm{x}$ solucan gübresi etkileşimi $\mathrm{p}<0.01$ göre önemli bulunmuştur (Tablo 3). Çeşitlerin en erken ortalama çıkış, tablo olum ve olgunlaşma süresi Pioneer 64LE119 (11.80, 92.13 ve 112.53 gün) çeşidinde, en erken tablo olum ve çiçeklenme süresi Pioneer 64LC108 (72.73 ve 91.73 gün) çeşidinden elde edilmiştir. [21], yapılan çalışmada, yağlık ayçiçeğinde erkenci çeşitlerde çiçeklenme süresinin tane verimi ve yağ oranı bakımından olumlu yönde etkisi olduğu bildirilmiștir. Bazı araştırmacıların yapmış oldukları araştırma sonuçlarına göre [17], çıkış süresi 13-17 gün arasında, tablo olum süresi 56-62 gün arasında ve olgunlaşma süresi 110-137 gün arasında [22], çıkış süresi 13.3-13.8 gün arasında, çiçeklenme süresini 84.2 gün ve olgunlaşma süresi 130.6-131.5 gün arasında, [19,23], çiçeklenme süresini 64-86 gün arasında ve [24], olgunlaşma süresi 110-137 gün arasında belirlemişlerdir. Bizim elde ettiğimiz veriler çeşitler bazında önemlilik arz etmese de araştırmacıların bulmuş olduğu sonuçlar ile uyum göstermemektedir. $\mathrm{Bu}$ farklllık çeşitlerin genetik özellikleri ve iklim faktörlerine bağlı olarak değişim gösterebilir. Nitekim bitkilerin çıkış, çiçeklenme, olgunlaşma gibi fenolojik özelliklerine iklim faktörlerinin önemli derecede etkisi olduğu gözlemlenmiștir [25]. 
Tablo 3. Fenolojik özelliklerine göre ayçiçeği çeșitlerine uygulanan vermikompost dozlarına ait ortalamalar ve varyans analiz sonuçları

\begin{tabular}{|c|c|c|c|c|c|}
\hline \multirow[b]{2}{*}{ Uygulamalar } & \multicolumn{5}{|c|}{ Fenolojik Özellikler } \\
\hline & & $\begin{array}{l}\text { Çılkış Süresi } \\
\text { (Gün) }\end{array}$ & $\begin{array}{c}\text { Tablo Olum } \\
\text { Süresi (Gün) }\end{array}$ & $\begin{array}{c}\text { Çiçeklenme } \\
\text { Süresi (Gün) }\end{array}$ & $\begin{array}{l}\text { Olgunlaşma } \\
\text { Süresi (Gün) }\end{array}$ \\
\hline \multirow{4}{*}{ Çeşitler } & Pioneer 64LE119 & 11.80 & 72.73 & 92.13 & 112.53 \\
\hline & Pioneer64LC108 & 12.53 & 72.73 & 91.73 & 112.60 \\
\hline & Ort. & 12.17 & 72.73 & 91.93 & 112.57 \\
\hline & 0 & 12.33 & 73.50 & 93.17 & 113.33 \\
\hline \multirow{5}{*}{$\begin{array}{l}\text { Vermikompost } \\
\text { (kg/da) }\end{array}$} & 100 & 11.17 & 72.67 & 92.33 & 112.17 \\
\hline & 200 & 12.50 & 72.67 & 91.83 & 112.33 \\
\hline & 300 & 12.33 & 72.50 & 90.50 & 112.83 \\
\hline & 400 & 12.50 & 72.33 & 91.83 & 112.17 \\
\hline & Ort. & 12.17 & 72.73 & 91.93 & 112.57 \\
\hline Varyasyon Analizi & S:D & \multicolumn{4}{|c|}{ Varyans Analizi } \\
\hline Ç & 1 & 1.48 & 0.00 & 2.77 & 0.03 \\
\hline $\mathrm{V}$ & 4 & 0.70 & 1.74 & $13.00^{* *}$ & 1.60 \\
\hline $\mathrm{ÇxV}$ & 4 & 0.90 & $3.21^{*}$ & $10.08^{* *}$ & $3.05^{*}$ \\
\hline
\end{tabular}

*\%5, ** \%1 seviyesinde önemlidir.

Solucan gübre dozlarına göre çıkış süresi en erken (11.17 gün) dekara $100 \mathrm{~kg}$ uygulandığında elde edilirken, en geç çıkış süresi (12.50 gün) dekara 200 ve $400 \mathrm{~kg}$ uygulandığında elde edilmiştir. Dekara 0, $100,200,300$ ve $400 \mathrm{~kg}$ solucan gübresi uygulamasında ayçiçeğinin tane dolum süresi sırasiyla 73.50, 72.67, 72.67, 72.50 ve 72.33 gün olarak belirlenmiștir. Solucan gübre seviyesi arttıkça ayçiçeğinin çiçeklenme süresi 93.17 günden (kontrol) 90.50 güne $(300 \mathrm{~kg} / \mathrm{da})$ gerilemiştir. $100,200,400$ $\mathrm{kg} / \mathrm{da}$ solucan gübresi uygulamasında ise sırasıyla 92.33, 91.83, 91.83 gün olarak tespit edilmiştir. Dekara $0,100,200,300$ ve $400 \mathrm{~kg}$ solucan gübresi uygulamasında ayçiçeği olgunlașma süresi sırasıyla 113.33, 112.17, 112.33, 112.83 ve 112.17 gün olarak ortaya çıkmıștır. Artan solucan gübresi dozlarına bağlı olarak ayçiçeğinin olgunlaşma süresinde dalgalanma olsa da kısalmasına neden olmuştur. [26], Siirt ekolojik koşullarında, Narcissus cv. 'Royal Connection' bitkisinin gelişimi üzerine katı ve sıvı solucan gübre dozlarının etkilerini incelemek amacıyla yapmıș oldukları çalıșmada; sıvı ve katı vermikompost gübrelerin en düșük dozlarının, kendi grupları içinde enerken tam çiçek oluşumunu erkene çekerek olumlu etki ettiği belirlenmiştir. Vermikompost kullanımı, sebzelerde ve süs bitkilerinde çiçeklenmeyi artırdığı görülmüştür [27]. [28] ve [29], vermikompost gübrenin süs bitkileri ve mantarın gelişimine olan etkilerini incelediklerinde, vermikompostun bitkilerin çiçeklenme süresine olumlu etkisi olduğunu gözlemlemișlerdir.

Morfolojik gözlemlerde çeşitler bazında yaprak sayısı, yaş sap verimi, kuru sap verimi, yaş tabla verimi ve kuru tabla verimi bakımından önemli bir farklılık görülmüştür. Bu uygulamada yaş sap ağırlığı ve kuru sap ağırlı̆̆ çeşitler bazında p<0.05 önemli iken diğer tüm özelliklerin çeşit, vermikompost ve çeşit $\mathrm{x}$ vermikompost interaksiyonları $\mathrm{p}<0.01$ göre önemli bulunmuștur (Tablo 4). Yaprak sayısı ve yaș tabla verimi bakımından çeşitler değerlendirildiğinde en yüksek yaprak sayısı ve yaş sap verimi (27.40 adet ve 692.76 kg/da) Pioneer 64LC108 çeşidinden elde edilirken yaş sap verimi, kuru sap verimi ve kuru tabla verimi bakımından çeşitler değerlendirildiğinde ise en yüksek yaș sap verimi, kuru sap verimi ve kuru tabla verimi (sirasiyla; 520.46, 143.24 ve 132.87 $\mathrm{kg} / \mathrm{da}$ ) Pioneer 64LE119 çeşidinden elde edilmiştir. [30], yapmıș oldukları çalıșmada ayçiçeği yaprak sayısının çeșitler bazında 27.63-29.35 adet arasında değişim gösterdiğini belirlemişlerdir. Elde edilen bazı sonuçlar ile bizim sonuçlar arasındaki farklılıklar çeşitlerin genetik özellikleri, çevresel ve iklimsel faktörlere bağlı olarak değişim göstermektedir. [31], farklı çerezlik ayçiçeği genotipleri ile Erzurum ekolojik şartlarında yapılan adaptasyon çalışmasında, sap verimi $605.2-1009.1 \mathrm{~kg} / \mathrm{da}$ olarak bulunmuştur. [18], ayçiçeği ile yapmış oldukları çalışmada sap verimini $238.3-251.2 \mathrm{~kg} / \mathrm{da}$ aralığında bulmuşlardır. Bizim sonuçlar bu sonuçlardan düşük çıkmıştır. Ayçiçeğinde sap verimi farklı ekolojik şartlara bağlı olarak değişim göstermektedir [32].

Farklı dozlarda solucan gübresi uygulamasında en yüksek yaprak sayısı ve yaş sap verimi (29.17 adet ve $591.90 \mathrm{~kg} / \mathrm{da}$ ) dekara $300 \mathrm{~kg}$ solucan gübresi dozundan elde edilirken, en düşük yaprak sayısı ve yaş sap verimi ise (24.33 adet ve $403.81 \mathrm{~kg} / \mathrm{da}$ ) solucan gübresi uygulanmadığında elde edilmiștir. Dekara 100, 200, $400 \mathrm{~kg}$ solucan gübresi uygulandığında yaprak sayısı sırasıyla $26.67,27.33$ ve 27.83 adet, yaş sap verimi $569.81,500.00$ ve 497.62 $\mathrm{kg} /$ da olarak belirlenmiștir. Denemenin en fazla kuru sap verimi $(160.48 \mathrm{~kg} / \mathrm{da})$ dekara $200 \mathrm{~kg}$ solucan gübresi dozundan, bunu takiben $0,100,300$ ve 400 $\mathrm{kg} / \mathrm{da}$ solucan gübresi dozlarında sırasıyla 130.67, $135.71,151.24$ ve $125.05 \mathrm{~kg} /$ da kuru sap verimi elde edilmiştir. 
Tablo 4. Morfolojik özelliklerine göre ayçiçeği çeşitlerine uygulanan vermikompost dozlarına ait ortalamalar ve varyans analiz sonuçları

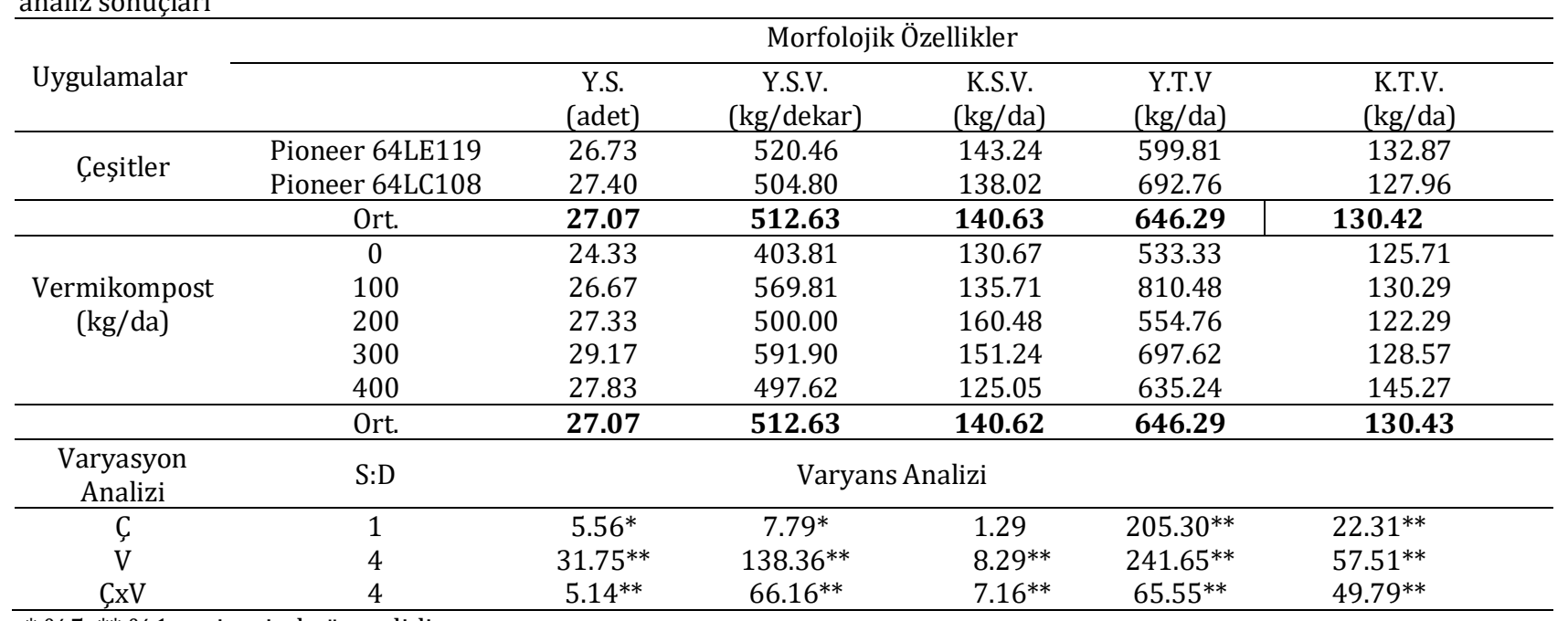

*\%5, ** \%1 seviyesinde önemlidir.

Solucan gübresi dozlarına göre, yaş tabla verimi 533.33-810.48 kg/da, kuru tabla verimi 122.29$145.27 \mathrm{~kg} / \mathrm{da}$ arasında değişmiştir. En yüksek yaş tabla verimi $810.48 \mathrm{~kg} /$ da ile dekara $100 \mathrm{~kg}$ solucan güresi uygulandığında, en yüksek kuru tabla verimi ise (145.27 kg/da) dekara $400 \mathrm{~kg}$ solucan güresi uygulandığında elde edilmiştir. Dekara 0, 200, 300 ve $400 \mathrm{~kg}$ solucan gübresi dozunda yaş tabla verimi sırasıyla 533.33, 554.76, 697.62 ve $635.24 \mathrm{~kg} / \mathrm{da}$ olarak gerçekleşmişken, dekara $0,100,200$ ve $300 \mathrm{~kg}$ solucan gübresi dozunda ise kuru tabla verimi sırasıyla $125.71,130.29,122.29$ ve $128.57 \mathrm{~kg} / \mathrm{da}$ olarak gerçekleşmiştir. Vermikompost gübre uygulaması bitkilerin besin ihtiyacını karşılarken, onların alımını da artırmaktadır. Ayrıca toprağın organik madde içeriğini artırmakta, toprağın hava almasını sağlamakta, toprağı fiziksel, kimyasal ve biyolojik yönden iyileştirmekte ve bitki verimini artırarak kaliteli ürün elde edilmektedir [33,34,15]. Organik tarım üretiminin önemli girdilerinden biri olduğu ve farklı bitkilere uygulanan vermikompost gübresinin bitki verim parametrelerine olumlu yönde etki ettiği birçok araştırmacı tarafından tespit edilmiştir [35,36,11].

Bitkilerde verimin belirlenmesi çok sayıda basit parametreler gözlemlenerek belirlenmeye çalıșılmaktadır. Verimin belirlenmesinde kullanılan bu parametrelere verim parametreleri denilmektedir. $\mathrm{Bu}$ parametreler verime doğrudan etki ettikleri gibi parametreler arasında ya doğrudan ya da dolaylı bir ilişki bulunmaktadır ve bu süreçte birbirlerine olan olumlu veya olumsuz etkileri korelasyon değerlerine göre belirlenir. Tablo 5'de farklı solucan gübresi uygulanan ayçiçeği çeşitlerinin korelasyon sonuçlarına göre; yaprak sayısı ve yaş sap verimi arasında pozitif ilişki $\left(0.411^{*}\right)$, olgunlaşma süresi ve yaş sap verimi arasında negatif ilişki $\left(-0.375^{*}\right)$, yaş sap verimi ve kuru sap verimi arasında pozitif ilişki $\left(0.366^{*}\right)$, yaş sap verimi ve kuru tabla verimi arasında Pozitif ilişki $\left(0.395^{*}\right)$ ve parametreler arasında \%5 düzeyinde önemli ilişki saptanırken, yaprak sayısı ve çiçeklenme süresi arasında negatif ilişki $\left(-0.679^{* *}\right)$, olgunlaşma süresi ve tablo olum süresi arasında pozitif ilişki $\left(0.698^{* *}\right)$, yaş tabla verimi ve yaş sap verimi arasında pozitif ilişki $\left(0.701^{* *}\right)$ ve bu korelasyonlar arasında \%1 seviyesinde önemli olumlu ilişkiler saptanmıştır. Diğer verim komponentleri arasında önemli bir farklılık olmadığı görülmektedir. [22], araştırma sonucunda, yaş sap verimi ile olgunlaşma süresi arasında $\left(0.824^{* *}\right)$ ve yaş sap verimi ile kuru sap verimi arasında (0.936**) pozitif yönde ilişki olduğunu tespit etmişlerdir.

Tablo 5. Parametreler arasındaki korelasyon (K.K) değerleri

\begin{tabular}{|l|c|c|c|c|c|c|c|c|c|}
\hline & Y.S & C.S & T.O.S & Çiçek S. & O.S & Y.S.V & K.S.V & Y.T.V & K.T.V \\
\hline Y.S & 1 & & & & & & & & \\
\hline C.S & 0,165 & 1 & & & & & & & \\
\hline T.O.S & $-0,139$ & $-0,145$ & 1 & & & & & & \\
\hline Çiçek S. & $-0,679^{* *}$ & $-0,027$ & 0,200 & 1 & & & & & \\
\hline O.S & 0,110 & $-0,091$ & $0,698^{* *}$ & $-0,090$ & 1 & & & & \\
\hline Y.S.V & $0,411^{*}$ & $-0,100$ & $-0,331$ & $-0,172$ & $-0,375^{*}$ & 1 & & & \\
\hline K.S.V & 0,143 & $-0,108$ & $-0,232$ & $-0,330$ & $-0,142$ & $0,366^{*}$ & 1 & & \\
\hline Y.T.V & 0,320 & $-0,054$ & $-0,240$ & $-0,006$ & $-0,266$ & $0,701^{* *}$ & $-0,096$ & 1 & \\
\hline K.T.V & $-0,029$ & $-0,107$ & $-0,208$ & 0,088 & $-0,350$ & $0,395^{*}$ & 0,015 & 0,189 & 1 \\
\hline
\end{tabular}

** \%1 seviyesinde önemlidir. Y.S: Yaprak sayısı, Ç.S: Çıkış süresi, T.O.S: Tabla olum süresi, Çiçek S: Çiçeklenme süresi, O.S: Olgunlaşma süresi, Y.S.A: Yaş sap verimi, K.S.A: Kuru sap verimi, Y.T.A: Yaş tabla verimi, K.T.A: Kuru tabla verimi 
Araștırmacıların bulmuş olduğu yaş sap verimi ve kuru sap verimi arasındaki pozitif ilişki ile bizim bulmuş olduğumuz sonuçlar ile paralellik gösterirken, yaş sap verimi ile olgunlaşma süresi arasında zit yönde ilişki bulunmuştur. Herhangi bir özelliğin verimle olan ilişkisinde korelasyon değerinin yüksek olmasına rağmen direk etkisinin düşük olması, diğer parametrelerin dolaylı etkilerinden kaynaklandığını ve bu parametrelerinde dikkate alınması gerektiğini belirtmişlerdir [37].

\section{Sonuç}

Ülkemizde bitkisel yağ üretimi için oldukça değerli olan ayçiçeğinin tamamen doğal organik gübreler kullanılarak üretiminin yapılması insan sağlığını ve çevremizi korumak adına önemli adımlardan bir tanesidir. Birçok araştırmacının vermikompost gübresinin toprak ve bitkiler üzerindeki etkisini belirlemek için yapmış oldukları çalışmalarda, vermikompost gübre uygulamalarının toprak için gerekli olan makro ve mikro besin element içeriğini zenginleştirdiğini, toprağın fiziksel yapısını iyileştirdiğinden önemli derecede toprak düzenleyicisi ve iyileştirici özelliği bulunduğunu belirtmişlerdir. Ayrıca bitkilerin çevresel, iklimsel, hastalık ve böcek zararlılarına karşı dayanımını artırdığı, çoğu bitkide verim artışının yanında ürün kalitesini artırdığı, özellikle yağ bitkilerinde yağ oranı ve kalitesinde önemli derecede iyileşme olduğunu gözlemlemişlerdir.

Bayburt ili sanayileşmenin olmadı̆̆ı ve üretimin ağırlıklı olarak ahır gübresi kullanılarak yapıldığı bakir bölgelerimizden bir tanesidir. $\mathrm{Bu}$ durum göz önüne alınarak Bayburt ekolojik koşullarında farklı dozlarda uygulanan vermikompost gübresinin yağlık ayçiçeği çeşitlerinde bazı fenolojik ve morfolojik özellikleri üzerine etkilerini belirlemek için yapılan çalışma sonucunda; çeşitler arasında en erken çıkış, tablo olum ve olgunlaşma süresi, en yüksek yaş sap verimi, kuru sap verimi ve kuru tabla verimi Pioneer 64LE119 çeşidinden, en erken tablo olum ve çiçeklenme süresi, en yüksek yaprak sayısı ve yaş sap verimi Pioneer 64LC108 çeşidinden elde edilmiştir. Solucan gübre dozlarına göre en erken çıkış süresi, en yüksek yaş tabla verimi dekara $100 \mathrm{~kg}$ gübre dozunda, en erken tane dolum süresi kontrolde, en erken çiçeklenme süresi, en yüksek yaprak sayısı ve yaş sap verimi dekara $300 \mathrm{~kg}$ gübre dozunda, en erken olgunlaşma süresi 100 ve $400 \mathrm{~kg}$ gübre dozlarında, en yüksek kuru sap verimi dekara $200 \mathrm{~kg}$ gübre dozunda, en yüksek kuru tabla verimi dekara $400 \mathrm{~kg}$ gübre dozunda elde edilmiştir.

Parametreler arasında en yüksek korelasyon ilişkisi yaş tabla verimi - yaş sap verimi ve olgunlaşma süresi - table olum süresi arasında meydana gelirken, negatif yönde en düşük yaprak sayısı - çiçeklenme süresi ve olgunlaşma süresi - yaş sap verimi arasında meydana gelmiştir. Sonuç olarak; sap verimi verileri dikkate alındığında 300 kg'lık vermikompost dozu ve Pioneer 64LC108 çeşidi önerilebileceği kanaatine varılmıștir.

\section{Teşekkür}

Bu çalışma Bayburt Üniversitesi Bilimsel Araştırma Projeleri Komisyonu, Bayburt, Türkiye tarafından finanse edilmiş ve desteklenmiștir (Proje kodu: 2017/02-69001-07).

\section{Kaynaklar}

[1] Arıoğlu, H. 1999. Yağ Bitkileri Yetiştirme ve Islahı. Çukurova Üniversitesi. Ziraat Fakültesi Yayınları No: 220, Adana, 204s.

[2] Göktaş, B., Gül, V. 2018. Türkiye'de tüketicilerin yağ alışkanlıkları ve satın aldıkları markalara yönelik düşünceler. (Temizer ve Baytal). Sosyal bilimlerde yeni yönelimler-V. I Baskl. Podgorica, Montenegro. İstitut za Geografiju, 359s.

[3] Gürbüz, B., Kaya, M.D., Demirtola, A. 2003. Ayçiçeği Tarımı. Hasad Yayıncılık. Ankara, 100s.

[4] Ghaffarzadeh, M. 2005. Ayçiçeği Yetiştirilmesi ve Üretimi www.pervasiz.com (Erișim 15.11.2018).

[5] Kırımhan, S. 2005. Organik Tarım Sistemleri ve Çevre. Uğurer Tarım Kitapları Bireysel Yayınları. Ankara, 350s.

[6] Akan, S., Yanmaz, R. 2015. Organik Gıdaların Besin Kalitesi ve İnsan Sağlığına Etkileri Yönünden Değerlendirilmesi. Doğu Karadeniz II. Organik Tarım Kongresi. 6-9 Ekim, Rize, 378386.

[7] Demir, H., Polat, E., Sönmez, İ. 2010. Ülkemiz İçin Yeni Bir Organik Gübre: Solucan Gübresi. Tarım Aktüel. (14). 54-60.

[8] Erşahin, Y. 2007. Vermikompost Ürünlerinin Eldesi ve Tarımsal Üretimde Kullanım Alternatifleri. Gaziosmanpaşa Üniversitesi, Ziraat Fakültesi Dergisi. 24(2). 99-107.

[9] Azarmi, R., Giglou, M.T., Talesmikail, R.D. 2008. Influence of vermicompost on soil chemical and physical properties in tomato (Lycopersicum esculentum) field. African Journal of Biotechnology. 7(14). 2397-2401.

[10] Atiyeh, R.A., Dominguez, J., Subler, S., Edwards, C.A. 2000. Changes in biochemical properties of cow manure during processing by earthworms (Eisenia andrei, Bouché) and the effects on seedling growth. Pedobiologia. 44 (6). 709-724.

[11] Yourtchi, M.S., Hadi, M.H.S., Darzi, M.T. 2013. Effect of nitrogen fertilizer and vermicompost on vegetative growth, yield and NPK uptake by tuber of potato (Agriacv.). International Journal of Agriculture and Crop Sciences. 5(18). 20332040. 
[12] Hernandez, A., Castillo, H., Ojeda, D., Arras, A., Lopez, J., Sanchez, E. 2010. Effect of vermicompost and compost on lettuce production. Chilean Journal of Agricultural Research. 70(4). 583-589.

[13] Büyükfiliz, $\quad$ F. 2016. Vermikompost gübrelemesinin ayçiçeği (Helianthus annuus L.) bitkisinin verim ve bazı kalite parametreleri üzerine etkisi, Namık Kemal Üniversitesi, Fen Bilimleri Enstitüsü, Toprak Bilimi ve Bitki Besleme Anabilim Dalı, Yüksek Lisans Tezi, 51s, Tekirdağ.

[14] Maltaş, A.Ş., Tavalı, İ.E., Uz, İ., Kaplan, M., 2017. Kırmızı Baş Lahana (Brassica Oleracea var. capitata F. rubra) Yetiştiriciliğinde Vermikompost Uygulaması. Mediterranean Agricultural Sciences. 30(2). 155-161.

[15] Singh, R., Sharma, R.R., Kumar, S., Gupta, R.K., Patil, R.T. 2008. Vermicompost substitution influences growth, physiological disorders, fruit yield and quality of strawberry (Fragaria $x$ ananassa Duch). Bioresource Technology. (99). 8507-8511.

[16] Kacar, B. 2009. Toprak Analizleri (ikinci Baskı). Nobel Yayıncilık. Ankara, 466s.

[17] Ergen, Y., Sağlam, C. 2005. Bazı Çerezlik Ayçiçeği (Helianthus annuus L.) Çeşitlerinin Tekirdağ Koşullarında Verim ve Verim Unsurları. Tekirdağ Üniversitesi Ziraat Fakültesi Dergisi. 2(3). 221-227.

[18] Tunçtürk, M., Eryiğit, T., Yılmaz, İ. 2005. VanErciş Koşullarında Bazı Ayçiçeği (Helianthus annuus L.) Çeşitlerinin Verim ve Verim Öğelerinin Belirlenmesi Uzer'ine Bir Araştırma. Türkiye VI. Tarla Bitkileri Kongresi. 5-9 Eylül, Antalya. 41-44.

[19] Evci, G., Pekcan, V., Yılmaz, İ.M., Kaya, Y,. Şahin, İ., Citak, N., Tuna, N., Ay, O., Pilasli, A. 2011. Ayçiçeğinde (Helianthus annuus L.) yăg kalitesi ve verim öğeleri arasındaki ilișkilerin belirlenmesi. Türkiye IX. Tarla Bitkileri Kongresi. 12-15 Eylül. Bursa, 279.

[20] Turan, Z.M. 1995. Araştırma ve Deneme Metotları. Uludağ Üniversitesi Ziraat Fakültesi Ders Notları No: 62, Bursa, 121s.

[21] Kaya, Y., Evci, G., Durak, S., Pekcan, V., Gücer, T. 2007. Determining The Relationships Between Yield And Yield Attributes İn Sunflower. Turkish. Journal of Agricultural and Forestry. (31). 237244.

[22] Gül, V., Kara, K. 2015. Effects of Different Nitrogen Doses On Yield And Quality Traits Of Common Sunflower (Helianthus annuus L). Turkish Journal of Field crop. 20(2). 159-165.

[23] Albayrak, Ș.N. 2014. Ekim zamanlarına göre uygulanan değişik azotlu gübre formlarının yağlık ayçiçeği (Helianthus annuus L.) çeşitlerinin verim ve verim unsurlarına etkisi, Atatürk Üniversitesi Fen Bilimleri Enstitüsü, Tarla Bitkileri Anabilim Dalı, Yüksek Lisans Tezi, 81s, Erzurum.

[24] Özer, H. 1999. Bazı Yağlık Ayçiçeği (Helianthus annuus L.) Ceșitlerinin Erzurum Ekolojik Koşullarında Adaptasyonu ve Önemli Tarımsal Özelliklerinin İncelenmesi, Atatürk Üniversitesi, Fen Bilimleri Enstitüsü, Tarla Bitkileri Anabilim Dalı, Yüksek Lisans Tezi, 43s, Erzurum.

[25] Bange, M.P., Hammer, G.L., Rickert, K.G. 1998. Temperature And Sowing Date Affect The Linear Increase Of Sunflower Harvest İndex. Agronomy Journal. 90(3). 324-328.

[26] Bademkıran, F., Çı̆̆, A., Türkoğlu, N. 2018. Nergis (Narcissus cv. 'Royal Connection') Bitkisinin Gelişimi Üzerine Katı ve Sıvı Solucan Gübresi Dozlarının Etkileri. Türk Tarım ve Doğa Bilimleri Dergisi. 5(4). 676-684.

[27] Edwards, C.A., Burrows, I. 1988. The potential of earthworm composts as plant growth me- dia. (In: Edwards, C. A., Neuhauser, E. (eds)) Earthworms in Waste and Environmental Management. SPB Academic Press, The Hague, The Netherlands, 21-32.

[28] Grappelli, A., Galli, E., Tomati, U. 1987. Earthworm Casting Effect On Agaricus Bisporus Fructification. Agrochimica. 31(4-5). 457-461.

[29] Tomati, U., Galli, E. 1995. Earthworms, Soil Fertility And Plant Productivity. Proceedings Of The International Colloquium On Soil Zoology. Acta Zoologica Fennica. 196. 11-14.

[30] Öztürk, F., Kızılgeçi, F. 2018. Farklı Ekim Zamanlarının Bazı Ayçiçeği (Helianthus Annuus L.) Genotiplerinin Verim ve Verim Unsurları Üzerine Etkileri. El-Cezerî Fen ve Mühendislik Dergisi. 5(3). 749-755.

[31] Özgödek, Z. 1993. Erzurum Ekolojik Şartlarında Yetiștirilen Bazı Cerezlik Ayçiçeği Ekotiplerinin Adaptasyonu ve Bazı Önemli Tarımsal Özelliklerinin İncelenmesi, Atatürk Üniversitesi Fen Bilimleri Enstitüsü, Tarla Bitkileri Anabilim Dalı, Yüksek Lisans Tezi, 49 s, Erzurum.

[32] Unger, P.W. 1980. Planting date effects on growth, yield, and oil of irrigated sunflowers. journal Agronomy. 72(6). 914-916.

[33] Peyvast, G., Olfati, J.A., Madeni, S., Forghani, A. 2007. Effect of Vermicompost on the Growth and Yield of Spinach (Spinacia oleracea L.). Journal of Food Agriculture and Environment. 6(1). 132135.

[34] Rangarajan, A., Leonard, B., Jack, A. 2008. Cabbage transplant production using organic media on farm. (In: Proceedings of National Seminar on Sustainable Environment. N. 
Sukumaran (Napoli, Curcuruto, \& Ruberto)). Bharathiar University, Coimbatore, 45-53s.

[35] Jahan, F.N., Shahjalal, A.T.M., Paul, A.K., Mehraj, H., Uddin, A.F.M.J. 2014. Efficacy of Vermicompost and Conventional Compost on Growth and Yield of Cauliflower. Bangladesh Research Publications Journal,.10 (1). 33-38.

[36] Adiloğlu, A., Eryılmaz. Açıkgöz, F., Adiloğlu, S., Solmaz, Y. 2015. Artan Miktarlarda Akuakültür
Atığı Uygulamasının Salata (Lactuca sativa L. var. crispa) Bitkisinin Bazı Makro ve Mikro Bitki Besin Elementi İçerikleri Üzerine Etkisi. Tekirdağ Ziraat Fakültesi Dergisi. 13(02). 96101.

[37] Kara, B., Akman, Z. 2007. Yerel buğday ekotiplerinde özelliklerarası ilişkiler ve path analizi. Süleyman Demirel Üniversitesi, Fen Bilimleri Enstitüsü Dergisi,.11(3). 219-224. 